\title{
Non-Conventional Metal Ion Cofactor Requirement of Dinoflagellate Alkaline Phosphatase and Translational Regulation by Phosphorus Limitation
}

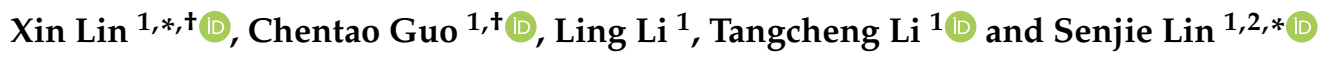 \\ 1 State Key Laboratory of Marine Environmental Science (MEL), Xiamen City Key Laboratory of Urban Sea \\ Ecological Conservation and Restoration (USER), Xiamen University, Xiamen 361102, China \\ 2 Department of Marine Sciences, University of Connecticut, Groton, CT 06405, USA \\ * Correspondence: xinlin@xmu.edu.cn (X.L.); senjie.lin@uconn.edu (S.L.); \\ Tel.: +86-592-2189772 (X.L.); +1-860-405-9168 (S.L.) \\ + These authors contributed equally to this work.
}

Received: 6 June 2019; Accepted: 30 July 2019; Published: 1 August 2019

\begin{abstract}
Alkaline phosphatase (AP) enables marine phytoplankton to utilize dissolved organic phosphorus (DOP) when dissolved inorganic phosphate (DIP) is depleted in the ocean. Dinoflagellate AP (Dino-AP) represents a newly classified atypical type of AP, PhoA ${ }^{\text {aty }}$. Despite While being a conventional $\mathrm{AP}, \mathrm{PhoA}^{\mathrm{EC}}$ is known to recruit $\mathrm{Zn}^{2+}$ and $\mathrm{Mg}^{2+}$ in the active center, and the cofactors required by PhoA aty have been contended and remain unclear. In this study, we investigated the metal ion requirement of AP in five dinoflagellate species. After AP activity was eliminated by using EDTA to chelate metal ions, the enzymatic activity could be recovered by the supplementation of $\mathrm{Ca}^{2+}, \mathrm{Mg}^{2+}$ and $\mathrm{Mn}^{2+}$ in all cases but not by that of $\mathrm{Zn}^{2+}$. Furthermore, the same analysis conducted on the purified recombinant ACAAP (AP of Amphidinium carterae) verified that the enzyme could be activated by $\mathrm{Ca}^{2+}, \mathrm{Mg}^{2+}$, and $\mathrm{Mn}^{2+}$ but not $\mathrm{Zn}^{2+}$. We further developed an antiserum against ACAAP, and a western blot analysis using this antibody showed a remarkable up-regulation of ACAAP under a phosphate limitation, consistent with elevated AP activity. The unconventional metal cofactor requirement of Dino-AP may be an adaptation to trace metal limitations in the ocean, which warrants further research to understand the niche differentiation between dinoflagellates and other phytoplankton that use $\mathrm{Zn}-\mathrm{Mg}$ AP in utilizing DOP.
\end{abstract}

Keywords: dinoflagellate; alkaline phosphatase; metal cofactor; inducible expression

\section{Introduction}

In marine ecosystems, the availability of $\mathrm{P}$ is critical to the growth of phytoplankton. Thus, $\mathrm{P}$ is often found to be the limiting nutrient of the primary productivity in the ocean $[1,2]$. In the ocean, $P$ is present in both inorganic and organic forms, among which dissolved inorganic phosphorus (DIP) as the preferred form for phytoplankton is quickly consumed and found at a low concentration in the euphotic zone [3]. In contrast, dissolved organic phosphorus (DOP) is relatively abundant in the euphotic zone. DOP mainly occurs in two forms: The major form phosphoesters and the less abundant form phosphonates [4,5]. When facing the DIP limited condition, phytoplankton are able to utilize a broad spectrum of phosphoesters to meet their cellular P requirement and sustain their primary production [6,7].

Enzymatic hydrolysis by alkaline phosphatase (AP) is a well-known mechanism employed by marine phytoplankton to utilize various types of phosphoesters which commonly features a phosphoester $(\mathrm{O}-\mathrm{P})$ bond. AP can release Pi from phosphoesters at the characteristic alkaline $\mathrm{pH}$ in the ocean [8]. Therefore, the presence and measurement of the bulk AP activity of phytoplankton has been 
used to indicate the P limitation in the ocean [2,7]. To gain further insights into the DOP utilization conveyed by AP in individual taxa, many studies have been conducted to examine the expression of AP coding genes and to characterize the enzyme properties in both marine bacteria and eukaryotic phytoplankton [9-12]. Experimental and genomic studies have revealed multiple types of APs which show not only substrate preferences but also different required metal ions as cofactors [13-17].

The conventional AP (PhoA $\left.{ }^{\mathrm{EC}}\right)$ initially identified in Escherichia coli was the best studied and defined as a homodimeric phosphomonoesterase. It mainly hydrolyzes phosphomonoesters with low activity on the phosphate diester and requires $2 \mathrm{Zn}-\mathrm{Mg}$ as bimetallo activity cores in the protein structure [18,19]. PhoA $^{\mathrm{EC}}$ has been documented in marine bacteria, cyanobacteria and diatoms $[12,13,20]$. The second type of AP with a determined protein folding structure is PhoX, which possesses a unique 3Ca-2Fe core [17] and exhibits a low substrate specificity for DOPs with an O-P bond [21,22]. Besides marine prokaryotes, PhoX homologs have also been identified in green algae, Volvox carteri and Chlamydomonas reinhardtii [23-25]. The third, rather common, type of AP in marine prokaryotes is PhoD, which has also been confirmed to be $\mathrm{Ca}^{2+}$-dependent and able to hydrolyze both phosphomonoesters and phosphodiesters $[13,26]$.

In addition, there are several uncategorized types of APs in marine phytoplankton. $\mathrm{A} \mathrm{Ca}^{2+}$-dependent putative AP was identified from the pelagophyte Aureoumbra lagunensis through a proteomic analysis [27]. A novel kind of AP, EHAP1, has also been identified in haptophyte Emiliania huxleyi [28]. Besides possessing an up-regulated PhoD under a P limitation [29], the diatom model Phaeodactylum tricornutum has been reported to own another type of AP with some sequence similarity to PhoA ${ }^{\mathrm{EC}}$, but its enzyme activity is enhanced by $\mathrm{Mn}^{2+}, \mathrm{Mg}^{2+}$ and $\mathrm{Ca}^{2+}$ instead of $\mathrm{Zn}^{2+}[12,30]$. Because of their high sequence variability, the structural and functional classification of these APs remains challenging. Though $\mathrm{PhoA}^{\mathrm{EC}}$ has been documented in marine bacteria, it is less frequently reported than the other two types in marine microbes. Taken together, the multiple types of APs and the prevalence of $\mathrm{Ca}^{2+}$-dependent APs are believed to be an adaptive mechanism which gives different marine microorganisms their niche advantages to utilize available types of phosphoesters under low metal ion availability conditions in the ocean [22].

Dinoflagellates are one of the most important groups of phytoplankton in the ocean and are well known to be capable of utilizing DOP with the aid of an AP under DIP-depleted conditions. Reports showed that the subcellular localization of the Dinoflagellate-AP (Dino-AP) can be both cell surface and intracellular [11,31]. Based on the genomic and transcriptomic data of the several dinoflagellate species currently available, only one type of AP has been identified in dinoflagellates, and we classified it as the PhoA $^{\text {aty }}$ type due to a generally high sequence divergence but recognizable conserved domains similar to an atypical PhoA type in cyanobacteria [32]. In these PhoA aty APs, we found conserved aspartic acid (D), glutamic acid (E) and a "proline-aspartic" motif amongst those conserved domains, a motif known to be responsible for $\mathrm{Ca}^{2+}$-binding, thus suggesting that $\mathrm{PhoA}^{\text {aty }}$ might also be a Ca ${ }^{2+}$-dependent type of AP [32]. However, this hypothesis has not yet been examined experimentally.

In this study, we investigated the metal ion requirement of APs in five dinoflagellate species (Amphidinium carterae, Alexandrium pacificum, Karenia mikimotoi, Prorocentrum minimum and Fugacium kawagutii) using an EDTA chelating and metal ion resupply approach. To better demonstrate the AP dependency on the metal ion, we overexpressed the AP gene of A. carterae (ACAAP) in E. coli, and enzymatic assays conducted on purified recombinant ACAAP ( $r$ ACAAP) verified that this AP could be activated by $\mathrm{Ca}^{2+}, \mathrm{Mg}^{2+}$, and $\mathrm{Mn}^{2+}$ but not $\mathrm{Zn}^{2+}$. We further developed a polyclonal antiserum against ACAAP, and a western blot analysis showed the remarkable up-regulation of ACAAP expression under a phosphate limitation and a positive correlation between ACAAP and AP activity, confirming the active function and translational regulation of this gene. 


\section{Materials and Methods}

\subsection{Algal Strains, Culture Conditions and Sample Collection}

Five dinoflagellate strains were used in this study. A. carterae and F. kawagutii (formerly Symbiodinium kawagutii) [33] were provided by the Provasoli-Guillard National Center for Marine Algae and Microbiota (NCMA); A. pacificum (formerly A. catenella) and P. minimum were provided by Center for Collections of Marine Bacteria and Phytoplankton, Xiamen University (CCMBP); and K. mikimotoi was provided by Jinan University. These strains were maintained in sterilized oceanic seawater (filtered through $0.22 \mu \mathrm{m}$ pore size filters, salinity $30 \mathrm{psu}$ ) enriched with the full nutrient regime of the $\mathrm{L} 1$ medium with no Si [34] in an incubator with temperature controlled at $20{ }^{\circ} \mathrm{C}$ (most examined strains) or $25^{\circ} \mathrm{C}$ (F. kawagutii) and illumination under a light dark cycle L:D = 12:12 (most examined strains) or 14:10 (F. kawagutii) with a photon flux of $100 \mu \mathrm{E} \mathrm{m}^{-2} \mathrm{~s}^{-1}$.

DIP-depleted and replete cultures (under the same condition as described above) were prepared in triplicates. The DIP-depleted cultures were grown under the same nutrient regime as DIP-replete cultures, except for a decreased phosphate concentration $(2 \mu \mathrm{M})$. The cell density in the culture was determined daily by the counting of the cells using a Sedgewick-Rafter counting chamber (Phycotech, St. Joseph, MI, USA). The DIP concentration in the culture media was measured using the Molybdate Blue method [35]. Cells from each culture $(200 \mathrm{~mL})$ were harvested by filtration onto $3 \mu \mathrm{m}$ pore size polycarbonate membranes (Millipore, Bedford, MA, USA) and washed off the membrane using an AP buffer (20 mM Tris- $\mathrm{HCl}, \mathrm{pH} 8.0,25 \mathrm{mM} \mathrm{NaCl}$ ). Harvested cells were homogenized by bead beating three times separately, using $0.5 \mathrm{~mm}$ ceramic beads with the setting of $6 \mathrm{~m} \mathrm{~s}^{-1}$ for $30 \mathrm{~s}$ on an MP FastPrep-24 (MP Biomedicals, CA, USA). After centrifugation at 13,000 $\mathrm{g}$ at $4{ }^{\circ} \mathrm{C}$ for $10 \mathrm{~min}$, the supernatant that contained extracted crude protein was subjected to enzyme activity measurements.

\subsection{Alkaline Phosphatase Activity Measurement on Algal Cells and Protein Extract}

The bulk AP activity of cultures was measured by adding $50 \mu \mathrm{L}$ of $20 \mathrm{mM}$ p-nitro-phenylphosphate (pNPP from Fluka, St. Louis, MO, USA), prepared in $1 \mathrm{M}$ Tris- $\mathrm{HCl}$ ( $\mathrm{pH}$ 8.0) into a $1 \mathrm{~mL}$ culture sample [36]. The reaction was carried out in sterile microcentrifuge tubes and incubated in darkness for $2 \mathrm{~h}$ at $25{ }^{\circ} \mathrm{C}$. After centrifugation at 10,000 $\mathrm{g}$ for $2 \mathrm{~min}$, the supernatant was removed and used for an OD measurement at $405 \mathrm{~nm}$ on a NanoDrop ND-2000 spectrophotometer (Thermo Scientific, Wilmington, DE, USA).

An in-gel AP activity assay was performed as described previously [27] with minor modifications. The extracted protein of $10^{6}$ A. carterae cells of both the P-depleted and the P-replete groups were incubated with a non-reducing Laemmli sample buffer at room temperature for 5 min and loaded into (4\%-10\%) SDS-PAGE gel, with an equal amount of protein in each well $(25 \mu \mathrm{g})$ and in triplicate for the P-depleted group. After electrophoresis, each gel lane was excised, soaked in an AP buffer (20 mM Tris- $\mathrm{HCl}, \mathrm{pH} 8.0,25 \mathrm{mM} \mathrm{NaCl})$ containing one of the three different metal ions $\left(10 \mathrm{mM} \mathrm{Ca}^{2+}, 10 \mathrm{mM}\right.$ $\mathrm{Mg}^{2+}, 0.1 \mathrm{mM} \mathrm{Zn^{2+ }}$ ), and incubated with ELF97 (1:50 dilution) (ELF ${ }^{\mathrm{TM}} 97$ endogenous phosphatase detection kit, Molecular Probes, OR, USA) for $2 \mathrm{~h}$ in the darkness at room temperature. For the P-replete group, each gel slice was subjected to the incubation with all three metal ions included to detect possible AP activity in one (instead of multiple) assay. Fluorescent gel images were acquired on the Bio-Rad Gel Doc XR system using an EtBr filter at $302 \mathrm{~nm}$ (Bio-Rad, CA, USA).

\subsection{Heterologous Expression of Recombinant ACAAP and Production of Antibody}

Based on the AP coding gene (acaap, GenBank: HQ259111.2) identified in A. carterae [36], two different kinds of amplicons were prepared and subjected to heterologous expression. A hydrophilic peptide ( $p$ ACAAP) comprising 180 amino acid residues (nucleotide site 661-1200) was used to generate a polyclonal antibody, and a recombinant ACAAP ( $r$ ACAAP) comprising 684 amino acid residues (full ORF region with the exclusion of a signal peptide coding region (nucleotide site 1-60)) was used for an enzyme activity analysis. Both gene fragments were amplified using specific primers (Table 1), 
and then gel-purified PCR products were cloned into vector pEasy-E1 (TransGen Biotech, Beijing, China) and transformed into E. coli BL21 (DE3). For each amplicon, a single colony containing the gene fragment was grown separately in a $3 \mathrm{~mL}$ LB (Luria-Bertani) liquid medium containing $100 \mu \mathrm{g} \mathrm{mL}$ ampicillin on a shaker rotating at $200 \mathrm{rpm}$ at $37^{\circ} \mathrm{C}$ for $16 \mathrm{~h}$; each colony was then transferred to $1 \mathrm{~L}$ fresh LB with $0.5 \mathrm{mM}$ IPTG (isopropyl- $\beta$-D-thiogalactopyranoside) to induce the expression of the inserted gene fragment, grown for $3 \mathrm{~h}$ at $37^{\circ} \mathrm{C}$ for $p$ ACAAP and $10 \mathrm{~h}$ at $28^{\circ} \mathrm{C}$ for $r \mathrm{ACAAP}$, both on a shaker rotating at $200 \mathrm{rpm}$.

Table 1. Primers used in this study.

\begin{tabular}{ccccc}
\hline Applications & Primer Name & Direction & Primer sequence $\left(5^{\prime}-\mathbf{3}^{\prime}\right)$ & PCR Condition \\
\hline \multirow{2}{*}{$p$ ACAAP } & PF1 & F & TTGAGCACATACACCGACGA & $94^{\circ} \mathrm{C} 3 \mathrm{~min}, 35$ cycles \\
& PR1 & R & AGATGCATTCAGATACATGATG & $\left(94^{\circ} \mathrm{C}, 30 \mathrm{~s}, 56^{\circ} \mathrm{C}, 45 \mathrm{~s}\right.$, \\
\multirow{2}{*}{ ACAAP } & PF2 & F & AAGGGACGTAGGCTTGCTAG & $\left.72{ }^{\circ} \mathrm{C}, 1 \mathrm{~min}\right), 72^{\circ} \mathrm{C}$, \\
& PR2 & R & CGCACGCACGGTCAAGAAG & $10 \mathrm{~min}$ \\
\hline
\end{tabular}

E. coli cells were harvested by centrifugation at $5000 \mathrm{~g}, 4{ }^{\circ} \mathrm{C}$ for $10 \mathrm{~min}$, resuspended in a 1 $\mathrm{mL}$ Tris- $\mathrm{HCl}$ buffer ( $50 \mathrm{mM}$ Tris- $\mathrm{HCl}, \mathrm{pH} 8.0)$, and then homogenized by ultrasonic treatment. After centrifugation at $15,000 \mathrm{~g}, 4{ }^{\circ} \mathrm{C}$ for $10 \mathrm{~min}$, the supernatant containing the heterologously-expressed peptide was purified using an Ni-NTA spin kit column (TransGen Biotech, Beijing, China) following the manufacturer's protocol. The resultant overexpressed peptide was loaded into a Superdex 75 gel filtration column on an AKTA prime liquid chromatography system (GE Healthcare Bio-Sciences, Uppsala, Sweden) and eluted using a phosphate-buffered saline buffer (PBS buffer, $50 \mathrm{mM} \mathrm{NaH}_{2} \mathrm{PO}_{4}$, $150 \mathrm{mM} \mathrm{NaCl}, \mathrm{pH}$ 8.0) as the mobile phase. All collected fractions were examined by sodium dodecyl sulfate polyacrylamide gel electrophoresis (SDS-PAGE), and fractions containing the target peptide were concentrated using Amicon Ultra centrifugal filter devices (Merck Millipore Ltd., Carrigtwohill, IRL). Purified $r$ ACAAP was subjected to further enzymatic characterization, and purified $p$ ACAAP was used to immunize a rabbit (Japanese white) to raise a polyclonal antiserum (Proteintech Group Inc., which has the laboratory animal license SYXK2014-0076 issued by Hubei Science Technology Department, Wuhan, China).

\subsection{Western Blot Analysis}

Crude protein, extracted as described above, was mixed with a reducing Laemmli buffer and incubated at $95{ }^{\circ} \mathrm{C}$ for $5 \mathrm{~min}$. The denatured proteins of each sample were loaded into $(4 \%-10 \%)$ SDS-PAGE gel (Bio-Rad, CA, USA) at equal amounts in each well. Electrophoresis was carried out at $90 \mathrm{~V}$ for $30 \mathrm{~min}$, followed by $120 \mathrm{~V}$ for $60 \mathrm{~min}$. The SDS-PAGE gel was then blotted onto a polyvinylidene fluoride (PVDF) membrane (Millipore, Bedford, MA, USA) at $25 \mathrm{~V}$ for $30 \mathrm{~min}$ using the Trans-Blot SD semi-dry transfer cell (Bio-Rad, CA, USA). The membranes were incubated in a blocking buffer containing $5 \%$ non-fat milk for $2 \mathrm{~h}$ at room temperature, followed by incubation with the polyclonal antiserum (1:5000 dilution) in TBS (Tris buffered saline) for $1 \mathrm{~h}$ at room temperature. After four washes with TBS containing 0.1\% Tween 20 (TBST), the membranes were incubated with a biotinylated goat anti-rabbit IgG (TransGen Biotech, Beijing, China) in a 1:10,000 dilution for $1 \mathrm{~h}$ at room temperature and then were washed four times in TBST. Meanwhile, the reference protein GAPDH (glyceraldehyde-3-phosphate dehydrogenase) was also examined using the monoclonal antibody (1:5000 dilution, Sangon Biotech, Shanghai, China) in parallel following the same procedure. The immunodetected bands were visualized using the enhanced chemiluminescent (ECL) substrate (Bio-Rad, CA, USA), and chemiluminescene images were acquired on a Bio-Rad Gel Doc XR system (Bio-Rad, CA, USA). The relative quantification of ACAAP expression was calculated in two ways, normalized to the ACAAP expression of P-replete on day 1 and normalized to reference protein GAPDH based on the band intensity estimated by Quantity One software (Bio-Rad, Hercules, CA, USA). 


\subsection{Metal Ion Dependency Analysis}

The metal ion requirement of APs was investigated in five dinoflagellate species and the purified $r$ ACAAP. The five dinoflagellate species were grown under the DIP-depleted condition as described above, and cells were collected at the stationary phase. For each enzymatic reaction, an equal amount of proteins (equal to $10^{4} \sim 10^{5}$ cells dependent on different species) were used. Pre-incubation with EDTA was employed to chelate the cellular metal ions present in the protein. The reaction mixture contained $6 \mu \mathrm{g}$ protein, $5 \mu \mathrm{L} 100 \mathrm{mM}$ EDTA, and $75 \mu \mathrm{L}$ AP buffer, and it was incubated at $25^{\circ} \mathrm{C}$ in the darkness for $30 \mathrm{~min}$ in a 96-well plate. Afterwards, $5 \mu \mathrm{L} 20 \mathrm{mM}$ pNPP was applied to the reaction mix along with $10 \mu \mathrm{L}$ of one of each of the following: $100 \mathrm{mM} \mathrm{Ca}^{2+}, 100 \mathrm{mM} \mathrm{Mg}^{2+}, 100 \mathrm{mM} \mathrm{Mn}^{2+}, 100 \mathrm{mM}$ $\mathrm{Co}^{2+}, 100 \mathrm{mM} \mathrm{Fe}^{3+}, 10 \mathrm{mM} \mathrm{Zn}^{2+}$, and $100 \mathrm{mM}$ EDTA (all prepared in $20 \mathrm{mM}$ Tris- $\mathrm{HCl} \mathrm{pH} \mathrm{8.0),} \mathrm{triplicate}$ wells for each treatment were done separately [13]. After another $2 \mathrm{~h}$ incubation, AP activity (APA) was measured on a SpectraMax Paradigm (Molecular Devices, CA, USA), and the spectrum reading of the control treatment (Ctrl) was taken as a base value to normalize the readings of other treatments to calculate the relative fold change of the enzyme activity as follows: $\left(\mathrm{APA}-\mathrm{APA} \mathrm{Ctrl}_{\mathrm{r}}\right) / \mathrm{APA}_{\mathrm{Ctrl}}$. Meanwhile, a control treatment was maintained in the preserved condition as pre-incubation, and $5 \mu \mathrm{L}\left(30 \mathrm{U}_{\mu} \mathrm{L}^{-1}\right)$ commercialized CIAP (calf intestinal alkaline phosphatase, Takara Bio Inc., Kusatsu, Shiga, Japan) were subjected to the same procedure as a positive reference.

\section{Results}

\subsection{Metal Ion Requirement of Dino-AP}

The metal ion requirement analysis was performed on crude protein extracts of $A$. carterae, $K$. mikimotoi, A. pacificum, P. minimum and F. kawagutii collected under the P-depleted condition. After pre-incubation with EDTA, AP activity disappeared (Figure 1). The AP activity was recovered significantly with the supplement of $\mathrm{Ca}^{2+}, \mathrm{Mg}^{2+}$ and $\mathrm{Mn}^{2+}$ in A. carterae, K. mikimotoi and A. pacificum (Tukey HSD, $p<0.01$, Figure 1a-c). In P. minimum, the AP activity was recovered significantly with the supplement of $\mathrm{Mg}^{2+}$ and $\mathrm{Mn}^{2+}$, while in F. kawagutii, the AP activity was recovered by $\mathrm{Mn}^{2+}$ but not significantly by $\mathrm{Ca}^{2+}$ and $\mathrm{Mg}^{2+}$ (Figure $1 \mathrm{~d}, \mathrm{e}$ ). To exclude the possibility that the apparent lack of AP activation by $\mathrm{Zn}^{2+}$ was due to a toxic effect of overdose, the commercialized CIAP was used as a control in the assay. In sharp contrast to dinoflagellate APs, the enzymatic activity of the CIAP was significantly recovered by the supply of $\mathrm{Mg}^{2+}$ and $\mathrm{Zn}^{2+}$ (Tukey HSD, $p<0.01$,) (Figure 1f), as documented of the conventional AP.

The same assay was tested on the purified $r$ ACAAP (heterologously expressed ACAAP in E. coli) incubated with the six metal ions separately following the same method as for algal cellular protein extracts. The result was consistent with the observation of crude protein extracts of $A$. carterae, and the AP activity of rACAAP was recovered significantly with the supplement of $\mathrm{Ca}^{2+}, \mathrm{Mg}^{2+}$, and $\mathrm{Mn}^{2+}$ (Tukey HSD, $p<0.01$ ), but not $\mathrm{Zn}^{2+}, \mathrm{Fe}^{3+}$ or $\mathrm{Co}^{2+}$ (Figure 1g). Meanwhile, the in-gel AP activity assay conducted on the crude protein extract of $A$. carterae revealed a unique positive protein band only in the P-depleted group with appended $\mathrm{Ca}^{2+}$, but there was negative in the P-depleted group with $\mathrm{Mg}^{2+}$ and $\mathrm{Zn}^{2+}$ and in the P-replete group (Figure 2). 


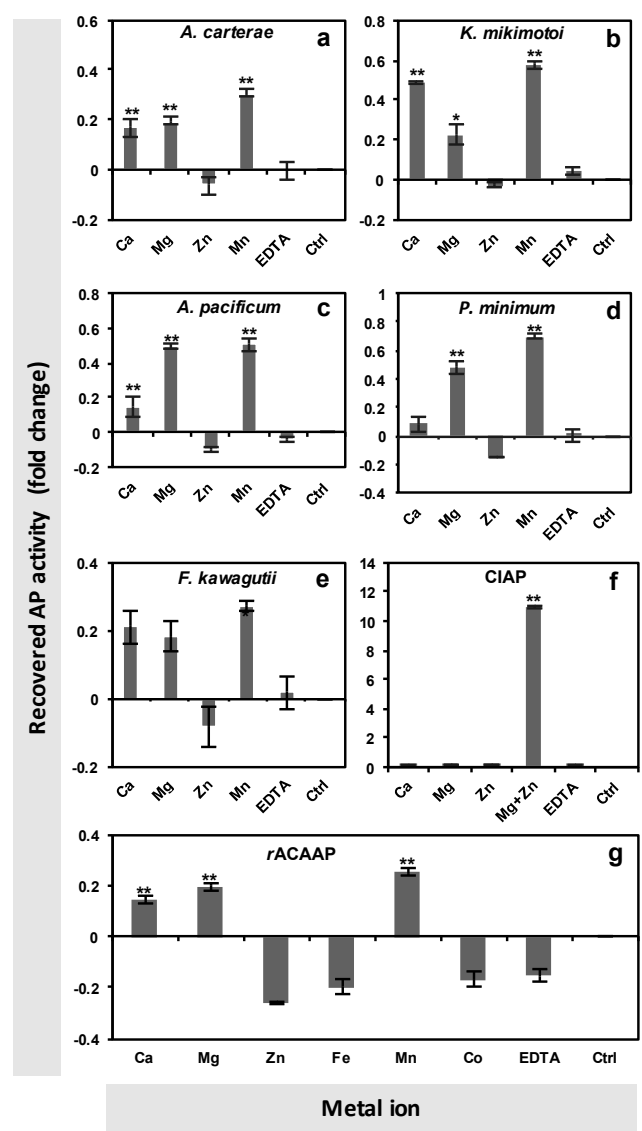

Figure 1. Alkaline phosphatase activity (APA) recovery of crude proteins of different dinoflagellate strains ((a) A. carterae, (b) K. mikimotoi, (c) A. pacificum, (d) P. minimum, (e) F. kawagutii), the commercialized CIAP (f) and the recombinant AP of A. carterae (rACAAP) (g) with the resupply of different metal ions after EDTA treatment to remove metals and eliminate APA. "Ctrl" represents the EDTA-pre-incubated reaction, which served as a blank control here. "EDTA" represents an experimental control that was resupplied with the same molar amount of EDTA as metal ions in experimental reactions. Asterisks depict the significant recovery of APA by metal ion resupply compared to the EDTA control (Tukey HSD, ${ }^{* *}$ represents $p<0.01,{ }^{*}$ represents $p<0.05$ ).

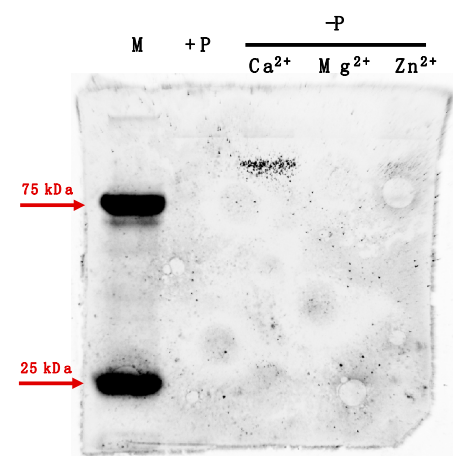

Figure 2. In-gel assay of metal ion specificity required by AP of A carterae. "M" represents protein marker, " $+\mathrm{P}^{\prime}$ represents extracted protein of the P-replete group, " $-\mathrm{P}$ " represents extracted protein of the P-depleted group incubated with specific metal ion respectively.

\subsection{Expression Pattern of AP in A. carterae (ACAAP) under Varied P Conditions}

A. carterae was grown in normal phosphate $(36 \mu \mathrm{M})$ and low phosphate $(2 \mu \mathrm{M})$ media. DIP concentration remained scarce (below the detection limit $0.2 \mu \mathrm{M}$ ) in the P-depleted group throughout the experiment. However, in the P-replete group, it was initially high $(25 \mu \mathrm{M})$ and then 
decreased quickly, reaching as low as that in the P-depleted group after day four (Figure 3a). Accordingly, markedly different growth curves were observed between two groups of cultures (Figure 3b). During the first three days, the cell densities in both groups increased steadily comparably, from $\sim 1.8 \times 10^{4}$ to $\sim 8.4 \times 10^{4}$ cells $\mathrm{mL}^{-1}$. The cells in the DIP-replete group continued the exponential growth until day five and then entered the stationary growth phase in a stable cell density. At the end of this experiment, the cell density of the DIP-replete culture was $2.4 \times 10^{5}$ cells $\mathrm{mL}^{-1}$, a 12-fold increase compared to the starting cell density. In the DIP-depleted group, the cultures grew more slowly after day three, and the cell density was $1.3 \times 10^{5}$ cells $\mathrm{mL}^{-1}$ at the end of this experiment-only about half of that in the DIP-replete group.

By comparison, AP activity started to diverge between the two groups earlier than did the cell density (Figure 3c). At the beginning of the experiment, AP activity was barely detectable in both groups. On day three, when the cell density was about the same between the two groups, AP activity in the P-depleted group (196 fmol pNP cell ${ }^{-1} \mathrm{~h}^{-1}$ ) increased dramatically to five-fold of that in the P-replete group ( $37 \mathrm{fmol} \mathrm{pNP} \mathrm{cell}{ }^{-1} \mathrm{~h}^{-1}$ ). Since then, the AP activity in the P-depleted group continued to increase quickly, while that in the DIP-replete group only increased slightly despite the significant drop of DIP concentration observed after day three (Figure 3a). At the end of this experiment, the AP activity in the DIP-depleted group (430 fmol pNP cell ${ }^{-1} \mathrm{~h}^{-1}$ ) was about four-fold of that in the DIP-replete group (99 fmol pNP cell ${ }^{-1} \mathrm{~h}^{-1}$ ).

a

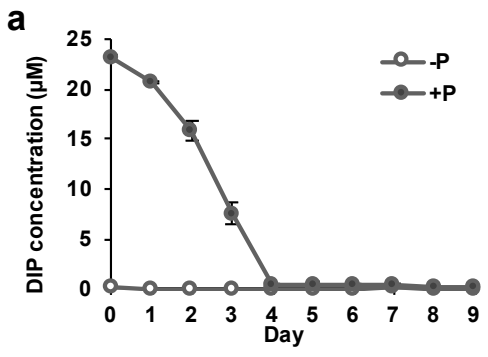

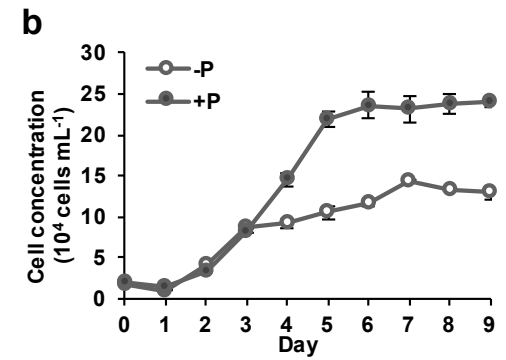

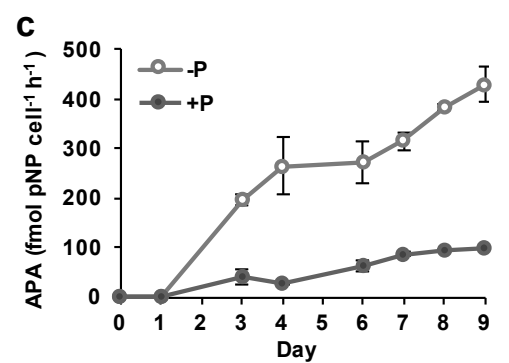

Figure 3. Dissolved inorganic phosphate (DIP) concentration (a), growth curve (b) and AP activity (c) in time course of $A$. carterae cultures under different phosphate conditions. $+\mathrm{P}$, normal phosphate concentration in an L1 medium; $-\mathrm{P}$, decreased phosphate concentration $(2 \mu \mathrm{M})$ in an otherwise L1 medium.

The extracted total proteins of $A$. carterae from both groups were subjected to SDS-PAGE and a western blot analysis. The result showed that the polyclonal antiserum raised against the $p$ ACAAP specifically detected a unique band, which lied between 100 and $150 \mathrm{kDa}$ (Figure 4a), apparently larger than computationally estimated $75 \mathrm{kDa}$ of ACAAP.

The immunodetected protein exhibited a significant difference in abundance between P-replete and P-depleted groups. A clear band was detected on day two and became thicker in the course of the experiment, indicating the inducible expression of ACCAP (Figure 4a). A remarkable up-regulation in the expression of ACCAP was observed in the DIP-depleted group compared to that in the DIP-replete group, regardless which normalization method used to evaluate the fold change of expression level (T-test, $p<0.05$ ) (Figure $4 \mathrm{~b}, \mathrm{c}$ ). The expression of ACAAP in the P-depleted group reached the peak on day four and maintained at a stable level until day seven, which was about $80 \%$ of that on day four, 21-fold of that on day one, and 57-fold of that in the P-replete group on day seven (Figure $4 \mathrm{~b}$ ). In contrast, the expression of ACAAP in the DIP-replete group generally maintained at low levels (shown as faint detected bands in gel, Figure 4a) throughout the experiment, despite the slight increase after the cultures entered the stationary phase (Figure $4 b, c)$. This result was consistent with the trend observed in AP activity (Figure 1c). Overall the protein expression of ACAAP was positively correlated with enzyme activity $\left(R^{2}=0.88, n=10\right.$, Figure $\left.4 d\right)$. 

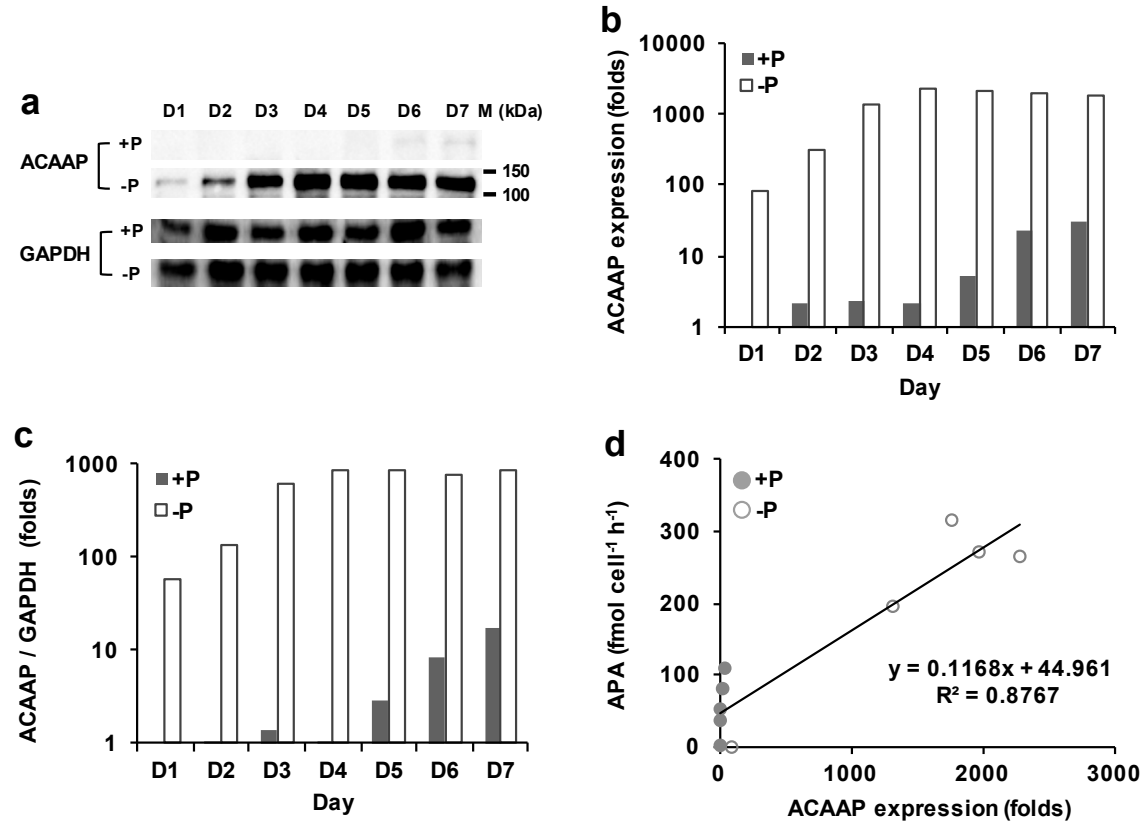

Figure 4. $\mathrm{AP}$ expression in $A$. carterae cultures grown under DIP-replete $(+\mathrm{P})$ and depleted $(-\mathrm{P})$ conditions. (a) ACAAP and glyceraldehyde-3-phosphate dehydrogenase (GAPDH) western blot. (b) Relatively quantified ACAAP expression. (c) ACAAP expression normalized to GAPDH. (d) Pearson correlation between ACAAP expression and APA $(p<0.05)$.

\section{Discussion}

\subsection{Inducible Expression of Dinoflagellate APs Through Transcriptional and Translational Regulation}

AP activities have been shown to be induced by $\mathrm{P}$ limitations in various dinoflagellate species in previous work [36-38], with which the results of the current study are consistent. Previously, the induction has been attributed to the transcriptional up-regulation of the AP gene under $\mathrm{P}$ limitations in dinoflagellate A. carterae, K. brevis and P. donghaiense $[36,37,39]$. In this study, using the antiserum developed against ACAAP in a western blot analysis, we observed the marked stimulation of AP protein expression in the DIP-depleted A. carterae, which was positively correlated with the AP activity increase. However, the magnitude of the increase in ACAAP abundance was much higher than in its activity. All these results suggest that the regulation of ACAAP expression and enzymatic activity in response to phosphate limitation lies at both the transcriptional level and the translational level, which is in agreement with the expression observed in EH-PhoA ${ }^{\text {aty }}$ of E. huxleyi [40]. Furthermore, the increase of both AP activity and AP expression appeared earlier than growth arrest in the P-depleted culture of $A$. carterae, and we noted a slight increase of both in the stationary growth phase of the P-replete group when there was a sharp drop in DIP concentration. Our previous study showed that $\mathrm{AP}$ of $A$. carterae was localized at both cell surface and intracellular compartment [11]. Taken together, these observations suggest that $A$. carterae might employ AP to utilize the intracellular DOP storage to maintain population growth when both DIP and DOP were deficient in the medium. Therefore, the expression of AP in A. carterae, and likely in other dinoflagellates as well, can be triggered by a low ambient Pi concentration, but it is really regulated by the internal $P$ availability, similar to the case of EH-PhoA aty [40].

\subsection{Evidence of Dinoflagellate AP Protein Modification from Observation on ACAAP}

The generation of ACAAP antiserum has enabled us to estimate the molecular size, besides abundance, of a dinoflagellate AP based on a western blot analysis. We noticed that there was a discrepancy in molecular mass between the ACAAP detected in SDS-PAGE ( 130 kDa) and the in silico prediction based on the amino acid sequence of ACAAP $(\sim 75 \mathrm{kDa})$. A striking coincidence occurred in 
PhoA $^{\text {aty }}$ of E. huxleyi (EH-PhoA ${ }^{\text {aty }}$ ), in which while the amino acid sequence gave a predicted molecular mass of $75 \mathrm{kDa}$, the detected band in the western blot lied between 100 and $120 \mathrm{kDa}, \sim 110 \mathrm{kDa}$ [40]. Our subsequent mass spectroscopic analysis showed that the $\sim 110 \mathrm{kDa}$ band was truly an EH- PhoA aty protein. One possibility is that the mature PhoA ${ }^{\text {aty }}$ type AP, of which both ACAAP and EH-PhoA ${ }^{\text {aty }}$ are, may function in a dimer-hinge conformation like the typical AP, PhoA ${ }^{\mathrm{EC}}$ [19]. Though protein complexes are usually broken in the protein denaturing buffer and SDS-PAGE, it cannot be ruled out that this AP holozyme may stay intact under these conditions. As documented, some stable dimers can remain un-dissociated in SDS-PAGE gel and able to perform enzyme activity [41,42]. Another possibility is that the post-translational modifications (PTMs) may occur and alter the molecular mass of the AP monomer or dimer, as has been reported previously for other proteins $[43,44]$. PTMs have been reported in algal APs. APs in the diatom P. tricornutum and the coccolithophorid E. huxleyi undergo proteolytic modification while released from the cell surface [12,28]. Our previous study proposed that the PhoA ${ }^{\text {aty }}$-type AP represents a phylogenetically distinct type of AP, sharing little sequence similarity to any other classified type of $\mathrm{AP}$, and, as such, their substrate preferences and protein structure still remain undetermined [32]. PTMs are of great importance to the biological function of proteins, including the enzyme activity state, subcellular localization, turnover and interactions with other proteins [43]. Thus, further efforts are required to investigate possible PTMs of PhoA ${ }^{\text {aty }}$ and their effects on enzymatic function.

\subsection{Metal Ion Requirement of Dino-AP}

Metal ions are indispensable for many enzymes to form and stabilize the conformational structure of folded proteins, providing the specific function in substrates binding and hydrolysis $[45,46]$. Besides transition metals ( $\mathrm{Fe}, \mathrm{Cu}$ and $\mathrm{Mn}$ ) previously found to be required particularly in biochemical redox process, the metalloproteins containing $\mathrm{Mg}, \mathrm{Ca}$ and $\mathrm{Zn}$ have also been extensively studied [45]. For instance, the archetypal PhoA ${ }^{\mathrm{EC}}$ has been well characterized and shown to require $2 \mathrm{Zn}-\mathrm{Mg}$ in each subunit to coordinate the active center, while another major characterized type of AP, PhoX, owns a complex active-site comprising $2 \mathrm{Fe}-3 \mathrm{Ca}[17,19,46]$. To implement the catalytic function, bimetallo cores require the transition metal $\mathrm{Fe}^{3+} / \mathrm{Zn}^{2+}$ to interact with the oxygen atoms of the O-P bond of the substrate molecule, the same as $\mathrm{Ca}^{2+}$ in PhoX $[19,46]$. Even though no available active site and structural model could be applied to PhoA ${ }^{\text {aty }}$, we have identified conserved motifs in PhoA ${ }^{\text {aty }}$, including residues of aspartic acid (D) and glutamic acid (E), that feature a high affinity to $\mathrm{Ca}^{2+}$ [47] and a highly conserved $\mathrm{Ca}^{2+}$-binding "proline-aspartic acid (PD)" motif shared by PhoX and phosphotriesterase $[17,21,32,48]$.

Consistent with the prediction, experiments in this study showed that the AP activity eliminated by metal iron depletion could be restored by the resupply of $\mathrm{Ca}^{2+}, \mathrm{Mn}^{2+}$ or $\mathrm{Mg}^{2+}$ in all five examined dinoflagellate strains but not by that of $\mathrm{Zn}^{2+}$. It is worth noting that $E$. huxleyi was able to express two different types of AP (EH-PhoA ${ }^{\text {aty }}$ and EHAP1) at the same time, and the AP activity of cell lysate (excluding most EHAP1 because it is secretory) could be restored more by $\mathrm{Ca}^{2+}$ than $\mathrm{Zn}^{2+}$ [40]. This result is comparable to the previous study carried out in the AP of other algae and PhoX of bacteria. Besides $\mathrm{Ca}^{2+}$ and $\mathrm{Fe}^{3+}$, the activity of PhoX can also be recovered with the presence of $\mathrm{Mn}^{2+}$ (shown in supplementary data in [17]) and $\mathrm{Mg}^{2+}$ [48]. A cell-surface AP isolated from P. minimum also exhibited the activity with the presence of both $\mathrm{Ca}^{2+}$ and $\mathrm{Mg}^{2+}[49,50]$, and the AP in dinoflagellate Pyrocystis noctiluca has previously been described as $\mathrm{Mg}^{2+}$-dependent [51]. A similar cofactor requirement was also observed in the diatom $P$. tricornutum, in which PhoA activity could be enhanced by $\mathrm{Mn}^{2+}, \mathrm{Mg}^{2+}$ and $\mathrm{Ca}^{2+}$, and the AP of the brown tide alga A. lagunensis was found to be $\mathrm{Ca}^{2+}$-dependent $[12,27]$. This compatibility may be due to the similar chemical characteristics shared by $\mathrm{Ca}^{2+}$ and $\mathrm{Mg}^{2+}$, as the $\mathrm{Mg}^{2+}$ binding residues also show preference for " $\mathrm{D}$ " as well as the $\mathrm{Ca}^{2+}$ binding site [52]. Nevertheless, there was a difference between the in-gel assay and the algal cell assay, in this study in that the resupply of $\mathrm{Mg}^{2+}$ and $\mathrm{Mn}^{2+}$ failed to recover AP activity (data not shown) in the in-gel assay, which can be explained as SDS-PAGE may disable protein conformational changes needed to accommodate these bivalent cations [53]. 
The prevalence of the $\mathrm{Ca}^{2+}$-dependent $\mathrm{AP}$ reported in marine microorganisms has been attributed to the relative low availability of $\mathrm{Zn}^{2+}$ in the ocean and the high abundance of $\mathrm{Ca}^{2+}$ and $\mathrm{Mg}^{2+}$ in the ocean $[1,14,16,22,27]$. Therefore, the adoption of $\mathrm{Ca}^{2+}$ in an AP may be an adaptive strategy that has evolved in the marine microorganisms in the $\mathrm{Zn}-\mathrm{P}$ co-limited environment. However, the identification of the $\mathrm{Ca}^{2+} / \mathrm{Fe}^{3+}$ active site of PhoX poses a possible Fe-deficiency based constrain of AP activity and a nutrient limitation-driven environmental selection of microorganism in the ocean $[17,54]$. We also noticed that the activity of the Dino-AP could also be recovered by the addition of $\mathrm{Mn}^{2+}$, one common transition metal found in metalloproteins, which, like $\mathrm{Ca}^{2+}$, is more abundant in the sea than $\mathrm{Zn}^{2+}[1]$.

In the PhoA ${ }^{\mathrm{EC}}$ family, the structural flexibility of the bimetallic site has been examined to interpret the promiscuous catalytic activity [46]. Structural comparisons of AP superfamily members showed distinct structure features outside of the conserved bimetallo site, which may not only impact specific substrate binding but may also modulate the properties of the bimetallo core to recognize substrates [19]. However, it is still unclear how $\mathrm{Ca}^{2+}$ and $\mathrm{Mn}^{2+}$ function in the active center of Dino-AP. Our results showed negative effect of $\mathrm{Zn}^{2+}$ on AP activity recovery in dinoflagellate, we also found resupply of $\mathrm{Zn}^{2+}+\mathrm{Mg}^{2+}$, like resupply of $\mathrm{Zn}^{2+}$ alone, did not recover AP (data not shown). However, without a further high-resolution structural observation of the AP proteins with metal ions inside, caution is required to interpret it as the dispensability or even antagonism of $\mathrm{Zn}^{2+}$ for dinoflagellate APs. Though we do not have crystallographic data to directly show the metal ion conformation of the Dino-AP protein, the possibility of an experimental artifact-for instance the addition of $\mathrm{Zn}^{2+}$, albeit only $1 \%$ dosage of other metal ions, caused toxic effects to the Dino-AP in our assays-is unequivocally excluded by the result of exactly the same assay for the calf intestinal alkaline phosphatase (CIAP), which exhibited total recovery of AP activity by the resupply of $\mathrm{Zn}^{2+}+\mathrm{Mg}^{2+}$, as expected of a conventional AP.

\section{Conclusions}

Dinoflagellate AP belongs to a newly classified type of AP, PhoA ${ }^{\text {aty }}$, and its enzyme expression and characterization has remained largely unexplored. This study is the first attempt to examine the metal ion cofactor requirement of the AP in core dinoflagellate species and develop an antibody to quantify AP abundance. Our results from five dinoflagellate species revealed that Dino-AP was activated by $\mathrm{Ca}^{2+}, \mathrm{Mg}^{2+}$ and $\mathrm{Mn}^{2+}$ but not by $\mathrm{Zn}^{2+}$. Additionally, the AP activity could be restored to different degrees by above-mentioned divalent cation among different species, in contrast to the conventional AP which requires the pair of $\mathrm{Zn}^{2+}+\mathrm{Mg}^{2+}$ as cofactors. Furthermore, our results showed for the first time that the mature enzyme of dinoflagellate APaty might function in a dimer-hinge conformation or undergo a post-translational modification that alters the molecular mass dramatically. These results, albeit a bit surprising, are not entirely unprecedented considering the similar behavior of the PhoA ${ }^{\text {aty }} \mathrm{AP}\left(\mathrm{EH}-\mathrm{PhoA}{ }^{\text {aty }}\right)$ in the haptophyte E. huxelyi and of other proteins in other organisms. Therefore, we propose here, with caution, that $\mathrm{PhoA}^{\text {aty }}$ may require unconventional metal ions such as $\mathrm{Ca}^{2+}$ as cofactors, which is likely a result of adaptive evolution under the selection pressure of limited or unpredictable trace metal availability in the ocean. Further study is required to illuminate the protein structure of PhoA $\mathrm{A}^{\text {aty }}$ and to determine the exact cofactor conformation in order to gain further understanding of the regulation of growth and the distribution of dinoflagellates from the perspective of $P$ nutrient strategy in the trace metal variable marine environment.

Author Contributions: Conceptualization, X.L. and S.L.; methodology, X.L., C.G. and L.L.; validation, C.G. and T.L.; formal analysis, C.G.; investigation, X.L. and C.G.; writing-original draft preparation, X.L., C.G. and S.L.; writing-review and editing, X.L. and S.L.; supervision, X.L. and S.L.; project administration, X.L. and S.L.; funding acquisition, X.L. and S.L.

Funding: This research was funded by the National Key Research and Development Program of China grant \# 2017YFC1404302 (S.L., X.L.), the National Natural Science Foundation of China grants \#41776116, \#31661143029 (S.L.) and \#41706116 (X.L.), Fundamental Research Funds for the Central Universities 20720180101 (X.L.).

Acknowledgments: We wish to thank Zhiyong Lin from Xiamen University for his technical assistance in protein purification using AKTA purifier. We thank Meizhen Li for her help with statistical analysis. 
Conflicts of Interest: The authors declare no conflict of interest. The funders had no role in the design, execution, interpretation, or writing of this study.

\section{References}

1. Moore, C.M.; Mills, M.M.; Arrigo, K.R.; Bermanfrank, I.; Bopp, L.; Boyd, P.W.; Galbraith, E.D.; Geider, R.J.; Guieu, C.; Jaccard, S.L.; et al. Processes and patterns of oceanic nutrient limitation. Nat. Geosci. 2013, 6, 701-710. [CrossRef]

2. Karl, D.M. Microbially mediated transformations of phosphorus in the sea: New views of an old cycle. Annu. Rev. Mar. Sci. 2014, 6, 279-337. [CrossRef] [PubMed]

3. Benitez-Nelson, C.R. The biogeochemical cycling of phosphorus in marine systems. Earth-Sci. Rev. 2000, 51, 109-135. [CrossRef]

4. Kolowith, L.C.; Ingall, E.D.; Benner, R. Composition and cycling of marine organic phosphorus. Limnol. Oceanogr. 2001, 46, 309-321. [CrossRef]

5. Paytan, A.; McLaughlin, K. The oceanic phosphorus cycle. Chem. Rev. 2007, 107, 563-576. [CrossRef]

6. Mather, R.L.; Reynolds, S.E.; Wolff, G.A.; Williams, R.G.; Torresvaldes, S.; Woodward, E.M.S.; Landolfi, A.; Pan, X.; Sanders, R.; Achterberg, E.P. Phosphorus cycling in the north and south atlantic ocean subtropical gyres. Nat. Geosci. 2008, 1, 439-443. [CrossRef]

7. Lin, S.; Litaker, R.W.; Sunda, W.G. Phosphorus physiological ecology and molecular mechanisms in marine phytoplankton. J. Phycol. 2016, 52, 10-36. [CrossRef] [PubMed]

8. Dyhrman, S.T.; Ammerman, J.W.; Mooy, B.A.S.V. Microbes and the marine phosphorus cycle. Oceanography 2007, 20, 110-116. [CrossRef]

9. Armbrust, E.V.; Berges, J.A.; Bowler, C.; Green, B.R.; Martinez, D.; Putnam, N.H.; Zhou, S.; Allen, A.E.; Apt, K.E.; Bechner, M.; et al. The genome of the diatom Thalassiosira pseudonana: Ecology, evolution, and metabolism. Science 2004, 306, 79-86. [CrossRef]

10. Dyhrman, S.T.; Jenkins, B.D.; Rynearson, T.A.; Saito, M.A.; Mercier, M.L.; Alexander, H.; Whitney, L.P.; Drzewianowski, A.; Bulygin, V.V.; Bertrand, E.M.; et al. The transcriptome and proteome of the diatom Thalassiosira pseudonana reveal a diverse phosphorus stress response. PLoS ONE 2012, 7, e33768. [CrossRef] [PubMed]

11. Lin, X.; Zhang, H.; Cui, Y.; Lin, S. High sequence variability, diverse subcellular localizations, and ecological implications of alkaline phosphatase in dinoflagellates and other eukaryotic phytoplankton. Front. Microbiol. 2012, 3, 235. [CrossRef] [PubMed]

12. Lin, H.Y.; Shih, C.Y.; Liu, H.C.; Chang, J.; Chen, Y.L.; Chen, Y.R.; Lin, H.T.; Chang, Y.Y.; Hsu, C.H.; Lin, H.J. Identification and characterization of an extracellular alkaline phosphatase in the marine diatom Phaeodactylum tricornutum. Mar. Biotechnol. 2013, 15, 425-436. [CrossRef] [PubMed]

13. Luo, H.; Benner, R.; Long, R.A.; Hu, J. Subcellular localization of marine bacterial alkaline phosphatases. Proc. Natl. Acad. Sci. USA 2009, 106, 21219-21223. [CrossRef] [PubMed]

14. Sebastian, M.; Ammerman, J.W. The Alkaline Phosphatase PhoX is more widely distributed in marine bacteria than the classical PhoA. ISME J. 2009, 3, 563-572. [CrossRef] [PubMed]

15. White, A.E. New insights into bacterial acquisition of phosphorus in the surface ocean. Proc. Natl. Acad. Sci. USA 2009, 106, 21013-21014. [CrossRef] [PubMed]

16. Kathuria, S.; Martiny, A.C. Prevalence of a calcium-based alkaline phosphatase associated with the marine cyanobacterium Prochlorococcus and other ocean bacteria. Environ. Microbiol. 2011, 13, 74-83. [CrossRef]

17. Yong, S.C.; Roversi, P.; Lillington, J.; Rodriguez, F.; Krehenbrink, M.; Zeldin, O.B.; Garman, E.F.; Lea, S.M.; Berks, B.C. A complex iron-calcium cofactor catalyzing phosphotransfer chemistry. Science 2014, 345, 1170-1173. [CrossRef]

18. Coleman, J.E. Structure and mechanism of alkaline phosphatase. Annu. Rev. Biophys. Biomol. Struct. 1992, 21, 441-483. [CrossRef]

19. Zalatan, J.G.; Fenn, T.D.; Brunger, A.T.; Herschlag, D. Structural and functional comparisons of nucleotide pyrophosphatase/phosphodiesterase and alkaline phosphatase: Implications for mechanism and evolution. Biochemistry 2006, 45, 9788-9803. [CrossRef] 
20. Luo, M.; Guo, Y.C.; Deng, J.Y.; Wei, H.P.; Zhang, Z.P.; Leng, Y.; Men, D.; Song, L.R.; Zhang, X.E.; Zhou, Y.F. Characterization of a monomeric heat-labile classical alkaline phosphatase from Anabaena sp. PCC7120. Biochemistry 2010, 75, 655. [CrossRef]

21. Zaheer, R.; Morton, R.; Proudfoot, M.; Yakunin, A.; Finan, T.M. Genetic and biochemical properties of an alkaline phosphatase PhoX family protein found in many bacteria. Environ. Microbiol. 2009, 11, 1572-1587. [CrossRef] [PubMed]

22. Sebastian, M.; Ammerman, J.W. Role of the phosphatase PhoX in the phosphorus metabolism of the marine bacterium Ruegeria pomeroyi DSS-3. Environ. Microbiol. Rep. 2011, 3, 535-542. [CrossRef] [PubMed]

23. Quisel, J.D.; Wykoff, D.D.; Grossman, A.R. Biochemical characterization of the extracellular phosphatases produced by phosphorus-deprived Chlamydomonas reinhardtii. Plant Physiol. 1996, 111, 839-848. [CrossRef] [PubMed]

24. Hallmann, A. Enzymes in the extracellular matrix of Volvox: An inducible, calcium-dependent phosphatase with a modular composition. J. Biol. Chem. 1999, 274, 1691-1697. [CrossRef]

25. Moseley, J.L.; Chang, C.W.; Grossman, A.R. Genome-based approaches to understanding phosphorus deprivation responses and PSR1 control in Chlamydomonas reinhardtii. Eukaryot. Cell 2006, 5, 26-44. [CrossRef]

26. Kageyama, H.; Tripathi, K.; Rai, A.K.; Chaum, S.; Waditeesirisattha, R.; Takabe, T. An alkaline phosphatase/phosphodiesterase, PhoD, induced by salt stress and secreted out of the cells of Aphanothece halophytica, a halotolerant cyanobacterium. Appl. Environ. Microbiol. 2011, 77, 5178-5183. [CrossRef] [PubMed]

27. Sun, M.M.; Sun, J.; Qiu, J.W.; Jing, H.; Liu, H. Characterization of the proteomic profiles of the brown tide alga Aureoumbra lagunensis under phosphate- and nitrogen-limiting conditions and of its phosphate limitation-specific protein with alkaline phosphatase activity. Appl. Environ. Microbiol. 2012, 78, 2025-2033. [CrossRef] [PubMed]

28. Xu, Y.; Wahlund, T.M.; Feng, L.; Shaked, Y.; Morel, F.M.M. A novel alkaline phosphatase in the Coccolithophore Emiliania huxleyi (Prymnesiophyceae) and its regulation by phosphorus. J. Phycol. 2006, 42, 835-844. [CrossRef]

29. Feng, T.Y.; Yang, Z.K.; Zheng, J.W.; Xie, Y.; Li, D.W.; Murugan, S.B.; Yang, W.D.; Liu, J.S.; Li, H.Y. Examination of metabolic responses to phosphorus limitation via proteomic analyses in the marine diatom Phaeodactylum tricornutum. Sci. Rep. 2015, 5, 10373. [CrossRef]

30. Bowler, C.; Allen, A.E.; Badger, J.H.; Grimwood, J.; Jabbari, K.; Kuo, A.; Maheswari, U.; Martens, C.; Maumus, F.; Otillar, R.P.; et al. The Phaeodactylum genome reveals the evolutionary history of diatom genomes. Nature 2008, 456, 239-244. [CrossRef]

31. Ou, L.; Qin, X.; Shi, X.; Feng, Q.; Zhang, S.; Lu, S.; Qi, Y. Alkaline phosphatase activities and regulation in three harmful Prorocentrum species from the coastal waters of the East China Sea. Microb. Ecol. 2019, 1-13. [CrossRef] [PubMed]

32. Lin, X.; Wang, L.; Shi, X.; Lin, S. Rapidly diverging evolution of an atypical alkaline phosphatase (PhoA $\left.{ }^{\text {aty }}\right)$ in marine phytoplankton: Insights from dinoflagellate alkaline phosphatases. Front. Microbiol. 2015, 6, 868. [CrossRef] [PubMed]

33. LaJeunesse, T.C.; Parkinson, J.E.; Gabrielson, P.W.; Jeong, H.J.; Reimer, J.D.; Voolstra, C.R.; Santos, S.R. Systematic revision of Symbiodiniaceae highlights the antiquity and diversity of coral endosymbionts. Curr. Biol. 2018, 28, 2570-2580. [CrossRef] [PubMed]

34. Guillard, R.R.L.; Hargraves, P.E. Stichochrysis immobilis is a diatom, not a chrysophyte. Phycologia 1993, 32, 234-236. [CrossRef]

35. Parsons, T.R.; Marita, Y.; Lalli, C.M. A Manual of Chemical and Biological Methods for Seawater Analysis, 1st ed.; Pergamon Press: Oxford, UK, 1984; pp. 22-25.

36. Lin, X.; Zhang, H.; Cui, Y.; Lin, S. Alkaline phosphatase gene sequence and transcriptional regulation by phosphate limitation in Amphidinium carterae (Dinophyceae). J. Phycol. 2011, 47, 1110-1120. [CrossRef] [PubMed]

37. Lin, X.; Zhang, H.; Cui, Y.; Lin, S. Alkaline phosphatase gene sequence characteristics and transcriptional regulation by phosphate limitation in Karenia brevis (Dinophyceae). Harmful Algae 2012, 17, 14-24. [CrossRef]

38. Zhang, C.; Lin, S.; Huang, L.; Lu, W.; Li, M.; Liu, S. Suppression subtraction hybridization analysis revealed regulation of some cell cycle and toxin genes in Alexandrium catenella by phosphate limitation. Harmful Algae 2014, 39, 26-39. [CrossRef] 
39. Shi, X.; Lin, X.; Li, L.; Palenik, B.; Lin, S. Transcriptomic and microRNAomic profiling reveals multi-faceted mechanisms to cope with phosphate stress in a dinoflagellate. ISME J. 2017, 11, 2209. [CrossRef] [PubMed]

40. Li, T.; Guo, C.; Zhang, Y.; Wang, C.; Lin, X.; Lin, S. Identification and expression analysis of an atypical alkaline phosphatase in Emiliania huxleyi. Front. Microbiol. 2018, 9, 2156. [CrossRef] [PubMed]

41. Gentile, F.; Amodeo, P.; Febbraio, F.; Picaro, F.; Motta, A.; Formisano, S.; Nucci, R. SDS-resistant active and thermostable dimers are obtained from the dissociation of homotetrameric $\beta$-Glycosidase from hyperthermophilic Sulfolobus solfataricus in SDS stabilizing role of the A-C intermonomeric interface. J. Biol. Chem. 2002, 277, 44050-44060. [CrossRef]

42. Rosen, R.F.; Tomidokoro, Y.; Ghiso, J.A.; Walker, L.C. SDS-PAGE/immunoblot detection of A $\beta$ multimers in human cortical tissue homogenates using antigen-epitope retrieval. J. Vis. Exp. 2010, 38, e1916.

43. Mann, M.; Jensen, O.N. Proteomic analysis of post-translational modifications. Nat. Biotechnol. 2003, 21, 255-261. [CrossRef] [PubMed]

44. Khoury, G.A.; Baliban, R.C.; Floudas, C.A. Proteome-wide post-translational modification statistics: Frequency analysis and curation of the swiss-prot database. Sci. Rep. 2011, 1, 1161-1166. [CrossRef] [PubMed]

45. Dudev, M.; Lim, C. Principles governing Mg, Ca, and Zn binding and selectivity in proteins. Chem. Rev. 2003, 103, 773-788. [CrossRef] [PubMed]

46. Hou, G.; Cui, Q. Stabilization of different types of transition states in a single enzyme active site: QM/MM analysis of enzymes in the alkaline phosphatase superfamily. J. Am. Chem. Soc. 2013, 135, 10457-10469. [CrossRef] [PubMed]

47. Jing, Z.; Liu, C.; Qi, R.; Ren, P. Many-body effect determines the selectivity for $\mathrm{Ca}^{2+}$ and $\mathrm{Mg}^{2+}$ in proteins. Proc. Natl. Acad. Sci. USA 2018, 115, E7495-E7501. [CrossRef] [PubMed]

48. Wu, J.R.; Shien, J.H.; Shieh, H.K.; Hu, C.C.; Gong, S.R.; Chen, L.Y.; Chang, P.C. Cloning of the gene and characterization of the enzymatic properties of the monomeric alkaline phosphatase (PhoX) from Pasteurella multocida strain X-73. FEMS Microbiol. Lett. 2007, 267, 113-120. [CrossRef] [PubMed]

49. Dyhrman, S.T.; Palenik, B.P. The identification and purification of a cell-surface alkaline phosphatase from the dinoflagellate Prorocentrum minimum (Dinophyceae). J. Phycol. 1997, 33, 602-612. [CrossRef]

50. Dyhrman, S.T. Ectoenzymes in Prorocentrum minimum. Harmful Algae 2005, 4, 619-627. [CrossRef]

51. Rivkin, R.; Swift, E. Characterization of alkaline phosphatase and organic phosphorous utilization in the oceanic dinoflagellate Pyrocystis noctiluca. Mar. Biol. 1980, 61, 1-8. [CrossRef]

52. Dudev, M.; Lim, C. Discovering structural motifs using a structural alphabet: Application to magnesium-binding sites. BMC Bioinform. 2007, 8, 106. [CrossRef] [PubMed]

53. Dudev, M.; Lim, C. Competition among metal ions for protein binding sites: Determinants of metal ion selectivity in proteins. Chem. Rev. 2013, 114, 538-556. [CrossRef] [PubMed]

54. Moore, C.M. Microbial proteins and oceanic nutrient cycles. Science 2014, 345, 1120-1121. [CrossRef] [PubMed]

(C) 2019 by the authors. Licensee MDPI, Basel, Switzerland. This article is an open access article distributed under the terms and conditions of the Creative Commons Attribution (CC BY) license (http://creativecommons.org/licenses/by/4.0/). 